\title{
СТАТЬИ
}

УДК 911.3:314.88(470.61) ДЕМОГРАФИЧЕСКИЙ ПОТЕНЦИАЛ И ПРОСТРАНСТВЕННОЕ РАЗВИТИЕ РОСТОВСКОЙ ОБЛАСТИ

\author{
Бессмертный И.В., Латун В.В., Меринова Ю.Ю., Хованский А.Д. \\ ФГБОУ ВО «Южный федеральный университет», Ростов-на-Дону, \\ e-mail: bessmertny74@gmail.com
}

Равномерность пространственного развития территории, выраженная в том числе особенностями системы расселения, концентрации жителей, уровнем демографического потенциала отдельных муниципальных образований, определяет возможности и интенсивность социального и экономического роста субъекта В контексте данного исследования демографический потенциал территории рассматривается авторами как совокупный показатель, учитывающий динамику численности населения в результате естественного и механического прироста, изменения в возрастной структуре населения и балансе трудовых ресурсов. Основной целью работы стало определение демографического потенциала Ростовской области и оценка возможностей воспроизводства населения в разрезе отдельных муниципальных образований и территориальных природноантропогенных комплексов региона. Ростовская область - один из наиболее экономически развитых и социально устойчивых регионов Юга России. С конца XX века в области отмечается депопуляция, определяемая как естественными, так и причинами социально-экономического характера. Данный процесс ведет к постепенному сокращению численности населения области, которое не компенсируется стабильным, но незначительным миграционным приростом. В условиях старения населения, депопуляции и дефицита рабочей силы в одних секторах и нарастающей безработицы в других в области отмечаются существенные территориальные диспропорции в демографической нагрузке. В результате исследования было выявлено, что пространственная дифференциация по сложности демографической ситуации меняется от экономически привлекательного и постоянно увеличивающего численность юго-запада, с опорным центром в городе, с населением более миллиона человек, Ростове-на-Дону, к все более стагнирующим, малозаселенным периферийным северной, северо-восточной и юго-восточной частям области, выделяющимся наименьшим демографическим потенциалом.

Ключевые слова: демографический потенциал, демографическая нагрузка, Ростовская область, пространственное развитие, интегральная оценка демографического потенциала

\section{DEMOGRAPHIC POTENTIAL AND SPATIAL DEVELOPMENT OF THE ROSTOV REGION}

\author{
Bessmertnyi I.V., Latun V.V., Merinova Yu.Yu., Khovanski A.D. \\ Southern Federal University, Rostov-in-Don, e-mail: bessmertny74@gmail.com
}

Abstract: The uniformity of territory spatial development, expressed, among other things, by the peculiarities of settlement system, the concentration of residents, the level of demographic potential of individual municipalities, determines the opportunities and intensity of socio-economic growth of the region. In the context of this study, the demographic potential of territory is seen as a cumulative indicator that considers population dynamics in natural population growth and migration gain, changes in population age structure and the balance of labor resources. The main goal of the work was to determine the demographic potential of the Rostov region and assess the possibilities of population reproduction in the context of individual municipalities and territorial natural and anthropogenic complexes of the region. Rostov Region is one of the most economically developed and socially stable regions of the South of Russia. Since the end of the XX century, depopulation has been noted in the region, determined by both natural and socio-economic reasons. This process leads to a gradual decrease in the region's population, which is not compensated by a stable, but insignificant migration increase. With an aging population, depopulation and labor shortages in some sectors and growing unemployment in other sectors, there are significant territorial disparities in the demographic load in the region. The study revealed that the spatial differentiation in terms of the complexity of the demographic situation is changing from the economically attractive and increasing population of the southwest to the stagnant northern, north-eastern and south-eastern parts of the region, with the lowest demographic potential.

Keywords: demographic potential, dependency ratio, Rostov region, spatial development, integral assessment of demographic potential

Пространственная организация населения является одним из важнейших факторов устойчивого развития региона. Система расселения и размещения производительных сил в ее территориальном проявлении представляет собой отправную точку, от которой формируются векторы дальнейшего социально-экономического роста субъектов.

В настоящее время региональные исследования приобретают все большую значимость в контексте сложившейся демографической ситуации, так как именно человеческий капитал отражает возможности развития экономики, кадровый, научный и производственный потенциал, благосостояние жителей и в конечном счете является основным двигателем экономического прогресса.

Для комплексной оценки демографической ситуации городов и муниципальных районов используется демографический 
потенциал территории. Этот показатель активно применяется в науке и практической деятельности, но, несмотря на это, единого общепризнанного подхода к его оценке среди исследователей нет.

Целью данной работы является оценка демографического потенциала Ростовской области и определение пространственных особенностей его формирования на современном этапе. муниципальных образований вычисляется как отношение числа пенсионеров к числу трудоспособных.

Для оценки демографического потенциала муниципальных районов Ростовской области была использована методика балльной оценки, включающая ранжирование вышеуказанных демографических показателей по 5-балльной шкале. Критерии оценивания представлены в табл. 1.

Критерии оценки демографического потенциала (составлено авторами)

\begin{tabular}{|c|c|c|c|c|c|}
\hline Балл & ЧН, тыс. чел. & ЕП, \%о & МП, \%о & ДН, чел. на 1000 населения & ЧР, тыс. чел \\
\hline 1 & Менее 20.0 & Менее -10 & Менее -10 & Более 900 & Менее 5 \\
\hline 2 & $20.1-50.0$ & $(-10):(-5)$ & $(-10):(-5)$ & $801-900$ & $5-10$ \\
\hline 3 & $50.1-250.0$ & $(-5): 0$ & $(-5): 0$ & $701-800$ & $10-50$ \\
\hline 4 & $250.1-1000$ & $0:+10$ & $0:+10$ & $601-700$ & $50-100$ \\
\hline 5 & Более 1000 & Более +10 & Более +10 & Менее 600 & Более 100 \\
\hline
\end{tabular}

\section{Материалы и методы исследования}

В контексте данного исследования демографический потенциал (далее - ДП) понимается как интегральный показатель, включающий совокупность величин, отражающих текущую численность населения и её изменение под влиянием естественного и механического движения, трудовые ресурсы и демографическую нагрузку в зависимости от возрастной структуры населения на определенной территории.

Для оценки демографического потенциала территории, с учётом возможных экономических последствий от сложившейся ситуации, рассматриваются особенности распределения численности постоянных жителей (далее - ЧН) и численности работающих (далее - ЧР). Исследование воспроизводства должно учитывать изучение динамики естественного (далее - ЕП) и миграционного прироста (далее - МП), выраженных показателями рождаемости, смертности, эмиграции и иммиграции.

Под демографической нагрузкой (далее - ДН) понимается обобщенная количественная характеристика возрастной структуры населения, характеризующая нагрузку со стороны неработающей части жителей на работающую [1]. Она складывается как сумма потенциальной и пенсионной нагрузки. Коэффициент потенциальной нагрузки рассчитывается как отношение количества населения в возрасте от 0 до 15 лет к числу трудоспособного населения определенной территории. Пенсионная нагрузка для всех
Все показатели рассматриваются в разрезе муниципальных районов и территориальных природно-антропогенных комплексов (далее - ТПАК) области. Районирование региона включает в себя 7 ТПАК: Юго-Западный, Донецкий, Центральный, Северо-Западный, Северо-Восточный, Южный и Юго-Восточный. Выделение семи вышеназванных ТПАК обусловлено природно-ресурсным потенциалом ландшафтов, общностью структуры экономики, демографических тенденций, развития социальной сферы и экологической ситуации входящих в них районов [2].

В исследовании использовались данные официальных статистических сборников по распределению населения Ростовской области в разрезе муниципальных образований, населенных пунктов различного ранга и людности, обработанные в соответствии с общепринятыми методиками. В процессе расчета и анализа демографических показателей применялись статистические и картографические методы исследования, метод комплексной оценки демографического потенциала.

\section{Результаты исследования и их обсуждение}

Численность населения. Ростовская область - регион со сложной демографической ситуацией, испытывающий с 1990-х годов сокращение численности постоянных жителей и централизацию располагаемого населения, что может привести к достаточно неблагоприятным последствиям 
в долгосрочной перспективе (табл. 1). Среднегодовая убыль населения области достигает 10,5 тыс. человек, с 1998 по 2018 г. население сократилось в общей сложности на 167 тысяч (3,8\%). Уровень урбанизации в регионе с традиционно высоким развитием аграрного хозяйства стабильно ниже среднероссийского значения $(68,2 \%)$, при этом прирост населения наблюдается почти исключительно в городах Ростовской агломерации, а доля селян ежегодно снижается (за 20 лет его доля упала с 32,3\% до 31,8 \%), табл. 2.

Изменения численности населения происходят за счет естественного и миграционного движения населения, которые характеризуются показателями рождаемости, смертности, эмиграции и иммиграции.

Рождаемость. Наибольшая рождаемость $(14 \%)$ отмечена в Батайске за счет повышенной доли молодых возрастов (до 40 лет) в общей структуре населения и высокой брачности. Среди муниципальных районов высокая рождаемость, превышающая среднеобластные значения, характерна для Кагальницкого и Мартыновского районов.

Повышенные показатели рождений (от 12,1\%о до 10,9\%о) наблюдаются в 12 административных единицах, что составляет четверть от всех муниципальных образований области. В основном они сконцентрированы в Юго-Западном комплексе (Ростов-на-Дону, Азов, Таганрог, Аксай и Мясниковский район), что объясняется более благоприятными социально-экономическими условиями для воспитания де- тей, нежели в более отдаленных районах области.

Пониженная рождаемость характерна для 19 районов области, 7 из которых расположены в Донецком комплексе (Донецк, Каменск, Шахты и др.), что объясняется большой долей пенсионеров и ухудшающимися социально-экономическими условиями, связанными с сокращением угледобывающего сектора, который является промышленной основой данного ТПАК. Наименьшие показатели рождаемости $(6,4-$ $7,9 \%$ ) отмечены в Гуково, Новошахтинске, Кашарском, Усть-Донецком, Чертковском районах.

Таким образом, оптимальными значениями рождаемости характеризуются Юго-Западный и Южный ТПАК, наименьшие значения свойственны для Донецкого и Северо-Западного комплексов, промежуточное положение занимают Северо-Восточный, Центральный и Юго-Восточный ТПАК (табл. 3).

Смертность. Рассматривая смертность населения, можно выделить муниципалитеты с наиболее благоприятной по этому показателю обстановкой (9,7-11,2\%), к которым относятся Ростов-на-Дону, Волгодонск, Аксайский, Заветинский и Мясниковский районы. Все они, за исключением Заветинского района, расположены в ЮгоЗападном комплексе.

Пониженные показатели смертности (11,4-13\%o) характерны для 7 административных образований (Батайск, Веселовский, Волгодонской, Зимовниковский, Октябрьский, Орловский и Ремонтненский районы).

Динамика численности населения Ростовской области [3; 4]

Таблица 2

\begin{tabular}{|c|c|c|c|}
\hline \multirow{2}{*}{ Годы } & \multirow{2}{*}{ Всего } & \multicolumn{2}{|c|}{ В том числе } \\
\cline { 3 - 4 } & & городское & сельское \\
\hline 1998 & 4387,6 & 2969,3 & 1418,3 \\
\hline 1999 & 4367,9 & 2953,1 & 1414,8 \\
\hline 2000 & 4340,8 & 2930,5 & 1410,3 \\
\hline 2002 & 4286,2 & 2892,0 & 1394,2 \\
\hline 2003 & 4396,7 & 2973,4 & 1423,3 \\
\hline 2004 & 4365,6 & 2952,4 & 1413,2 \\
\hline 2005 & 4334,4 & 2892,7 & 1441,7 \\
\hline 2010 & 4283,9 & 2879,1 & 1404,8 \\
\hline 2012 & 4260,6 & 2876,3 & 1381,3 \\
\hline 2013 & 4254,6 & 2878,3 & 1376,3 \\
\hline 2014 & 4243,8 & 2878,7 & 1365,1 \\
\hline 2015 & 4239,0 & 2875,5 & 1363,5 \\
\hline 2016 & 4233,7 & 2873,1 & 1360,6 \\
\hline 2017 & 4231,3 & 2874,0 & 1357,3 \\
\hline 2018 & 4220,4 & 2871,4 & 1349,0 \\
\hline
\end{tabular}


Таблица 3

Балльная оценка демографического потенциала в городских округах и административных районах Ростовской области, 2017 г. (составлено авторами)

\begin{tabular}{|c|c|c|c|c|c|c|c|c|c|c|c|}
\hline Районы & $\begin{array}{l}\text { ЧН, тыс. } \\
\text { человек }\end{array}$ & క్ & $\begin{array}{l}\text { ЕП, } \\
\% о\end{array}$ & క్ & $\underset{\%}{\mathrm{M \Pi},}$ & 苞 & $\begin{array}{l}\text { Численность } \\
\text { работающих, } \\
\text { тыс. человек }\end{array}$ & క్ & $\begin{array}{l}\text { ДН, } \\
\text { чел. }\end{array}$ & క్ & $\begin{array}{c}\text { Сред- } \\
\text { ний } \\
\text { балл }\end{array}$ \\
\hline Юго-Западный & 2169,7 & 2,8 & $-2,87$ & 2,8 & 4,10 & 3,6 & 679,9 & 2,8 & 741 & 2.6 & 3 \\
\hline г. Ростов-на-Дону & 1125,3 & 5 & 0 & 3 & 4,42 & 4 & 423,3 & 5 & 694 & 4 & 4,2 \\
\hline г. Азов & 81,3 & 3 & $-1,9$ & 3 & $-5,66$ & 2 & 23,4 & 3 & 849 & 2 & 2,6 \\
\hline г. Батайск & 124,7 & 3 & 2,6 & 4 & 13,93 & 5 & 25,9 & 3 & 759 & 3 & 3,8 \\
\hline г. Новочеркасск & 168,8 & 3 & -4 & 3 & $-0,42$ & 3 & 47,9 & 3 & 673 & 4 & 3,2 \\
\hline г. Таганрог & 250,3 & 4 & $-4,5$ & 3 & 2,71 & 4 & 79,3 & 4 & 878 & 2 & 3,4 \\
\hline Азовский & 97 & 3 & $-3,4$ & 3 & 2,99 & 4 & 12,5 & 3 & 821 & 2 & 3,0 \\
\hline Аксайский & 113,3 & 3 & 0,8 & 4 & 11,41 & 5 & 33,5 & 3 & 713 & 3 & 3,6 \\
\hline Куйбышевский & 13,9 & 1 & $-5,8$ & 2 & $-3,38$ & 3 & 2,0 & 1 & 882 & 2 & 1,8 \\
\hline Матвеево-Курганский & 40,6 & 2 & $-6,4$ & 2 & $-7,98$ & 2 & 7,0 & 2 & 871 & 2 & 2,0 \\
\hline Мясниковский & 46,8 & 2 & 0,5 & 3 & 22,76 & 5 & 10,8 & 3 & 755 & 3 & 3,4 \\
\hline Неклиновский & 85,5 & 3 & $-5,4$ & 2 & $-1,92$ & 3 & 10,8 & 3 & 887 & 2 & 2,6 \\
\hline Родионово-Несветайский & 22,2 & 2 & $-6,9$ & 2 & $-3,74$ & 3 & 3,5 & 1 & 827 & 2 & 2,0 \\
\hline Донецкий & 916,6 & 2.4 & $-6,79$ & 2.2 & $-1,88$ & 2.9 & 179,5 & 2.5 & 877 & 1.8 & 2.4 \\
\hline г. Шахты & 235,5 & 3 & $-4,7$ & 3 & $-2,46$ & 3 & 43,0 & 3 & 833 & 2 & 2,8 \\
\hline г. Новошахтинск & 108,8 & 3 & $-6,4$ & 2 & 2,40 & 4 & 15,0 & 3 & 814 & 2 & 2,8 \\
\hline г. Каменск-Шахтинский & 89,6 & 2 & $-6,4$ & 2 & $-1,02$ & 3 & 27,8 & 3 & 846 & 2 & 2,4 \\
\hline г. Гуково & 66,3 & 3 & $-8,7$ & 2 & $-13,38$ & 1 & 9,3 & 2 & 914 & 1 & 1,8 \\
\hline г. Донецк & 48,4 & 2 & $-6,2$ & 2 & $-7,46$ & 2 & 6,8 & 2 & 897 & 2 & 2,0 \\
\hline г. Зверево & 21,1 & 2 & $-7,4$ & 2 & $-12,37$ & 1 & 5,5 & 2 & 843 & 2 & 1,8 \\
\hline Белокалитвенский & 92 & 3 & $-6,8$ & 2 & $-6,92$ & 2 & 20,0 & 3 & 973 & 1 & 2,2 \\
\hline Каменский & 41,8 & 2 & $-8,6$ & 2 & $-4,64$ & 3 & 7,9 & 2 & 944 & 1 & 2,0 \\
\hline Красносулинский & 75,4 & 3 & $-7,3$ & 2 & 0,17 & 4 & 14,9 & 3 & 893 & 2 & 2,8 \\
\hline Октябрьский & 71,2 & 2 & -4 & 3 & 14,24 & 5 & 16,6 & 3 & 705 & 3 & 3,2 \\
\hline Тацинский & 34,7 & 2 & $-7,8$ & 2 & $-4,78$ & 3 & 7,2 & 2 & 863 & 2 & 2,2 \\
\hline Усть-Донецкий & 31,8 & 2 & $-7,2$ & 2 & 5,06 & 4 & 5,0 & 2 & 886 & 2 & 2,4 \\
\hline Центральный & 415,4 & 2.1 & $-2,55$ & 2.9 & $-2,37$ & 2.5 & 87,2 & 1.8 & 861 & 1.9 & 2.3 \\
\hline г. Волгодонск & 171,5 & 3 & $-0,7$ & 3 & 2,17 & 4 & 50,3 & 4 & 855 & 2 & 3,4 \\
\hline Багаевский & 34,7 & 2 & -1 & 3 & $-10,1$ & 1 & 4,3 & 1 & 885 & 2 & 1,8 \\
\hline Веселовский & 25,5 & 2 & $-2,9$ & 3 & $-1,88$ & 3 & 4,3 & 1 & 798 & 3 & 2,4 \\
\hline Волгодонской & 33,8 & 2 & $-1,6$ & 3 & $-6,89$ & 2 & 3,4 & 1 & 832 & 2 & 2,0 \\
\hline Константиновский & 31,6 & 2 & $-5,1$ & 2 & $-6,90$ & 2 & 5,5 & 2 & 822 & 2 & 2,0 \\
\hline Мартыновский & 34,5 & 2 & -2 & 3 & $-2,78$ & 3 & 4,8 & 1 & 911 & 1 & 2,0 \\
\hline Пролетарский & 34,5 & 2 & $-3,4$ & 3 & $-9,39$ & 2 & 5,8 & 2 & 836 & 2 & 2,2 \\
\hline Семикаракорский & 49,3 & 2 & $-3,7$ & 3 & $-1,89$ & 3 & 8,6 & 2 & 939 & 1 & 2,2 \\
\hline Северо-Западный & 209,1 & 1.9 & $-7,5$ & 2 & $-2,94$ & 2.6 & 41,1 & 1.6 & 861 & 1.9 & 2 \\
\hline Боковский & 14,2 & 1 & $-5,1$ & 2 & $-5,49$ & 2 & 2,5 & 1 & 876 & 2 & 1,6 \\
\hline Верхнедонской & 18,1 & 1 & $-8,6$ & 2 & $-6,08$ & 2 & 3,3 & 1 & 923 & 1 & 1,4 \\
\hline Кашарский & 23,7 & 2 & -9 & 2 & $-6,71$ & 2 & 3,7 & 1 & 825 & 2 & 1,8 \\
\hline Миллеровский & 65 & 3 & $-5,9$ & 2 & $-0,49$ & 3 & 15,7 & 3 & 847 & 2 & 2,6 \\
\hline Тарасовский & 28,4 & 2 & $-8,7$ & 2 & 1,83 & 4 & 4.7 & 1 & 869 & 2 & 2,2 \\
\hline Чертковский & 33,8 & 2 & $-8,7$ & 2 & $-4,32$ & 3 & 6,0 & 2 & 869 & 2 & 2,2 \\
\hline Шолоховский & 25,9 & 2 & $-6,5$ & 2 & $-5,48$ & 2 & 5,2 & 2 & 885 & 2 & 2,0 \\
\hline Северо-Восточный & 109,4 & 1.4 & $-6,02$ & 2.4 & $-5,16$ & 2.6 & 21,6 & 1.4 & 892 & 1.6 & 1.9 \\
\hline Милютинский & 13,3 & 1 & $-8,5$ & 2 & $-9,40$ & 2 & 2,6 & 1 & 934 & 1 & 1,4 \\
\hline Морозовский & 38,8 & 2 & $-4,9$ & 3 & $-8,51$ & 2 & 8,4 & 2 & 893 & 2 & 2,2 \\
\hline Обливский & 17,6 & 1 & $-6,2$ & 2 & $-5,51$ & 2 & 2,8 & $\frac{2}{1}$ & 812 & 2 & 1,6 \\
\hline Советский & 6,3 & 1 & $-4,9$ & 3 & $-4,29$ & 3 & 0,9 & 1 & 819 & 2 & 2,0 \\
\hline Цимлянский & 33,4 & 2 & $-5,6$ & 2 & 0,45 & 4 & 6,9 & 2 & 932 & 1 & 2,2 \\
\hline Южный & 277,2 & 2.3 & $-4,17$ & 2.7 & $-8,04$ & 1.7 & 54,6 & 2.3 & 879 & 1.8 & 2.2 \\
\hline Егорлыкский & 33,7 & 2 & $-1,4$ & 3 & $-9,20$ & 2 & 5,0 & 2 & 866 & 2 & 2,2 \\
\hline Зерноградский & 53,7 & 3 & $-5,0$ & 2 & $-5,55$ & 2 & 11,5 & 3 & 871 & 2 & 2,4 \\
\hline
\end{tabular}




\begin{tabular}{|c|c|c|c|c|c|c|c|c|c|c|c|}
\hline \multicolumn{12}{|c|}{ Окончание табл. 3} \\
\hline Районы & $\begin{array}{l}\text { ЧН, тыс. } \\
\text { человек }\end{array}$ & క్ & $\begin{array}{l}\mathrm{E \Pi ,} \\
\% о\end{array}$ & క్ & $\begin{array}{c}\text { МП, } \\
\% \text {, }\end{array}$ & క్ & $\begin{array}{l}\text { Численность } \\
\text { работающих, } \\
\text { тыс. человек }\end{array}$ & 志 & $\begin{array}{l}\text { ДН, } \\
\text { чел. }\end{array}$ & క్ & $\begin{array}{c}\text { Сред- } \\
\text { ний } \\
\text { балл }\end{array}$ \\
\hline Кагальницкий & 28,2 & 2 & $-3,1$ & 3 & $-12,77$ & 1 & 6,2 & 2 & 882 & 2 & 2,0 \\
\hline Песчанокопский & 28,2 & 2 & $-7,8$ & 2 & $-14,75$ & 1 & 5,0 & 2 & 939 & 1 & 1,6 \\
\hline Сальский & 102,7 & 3 & $-3,9$ & 3 & $-4,48$ & 3 & 21,2 & 3 & 869 & 2 & 2,8 \\
\hline Целинский & 30,7 & 2 & $-3,8$ & 3 & $-12,57$ & 1 & 5,7 & 2 & 883 & 2 & 2,0 \\
\hline Юго-Восточный & 131,2 & 1.6 & $-1,86$ & 3 & $-6,56$ & 2.6 & 21,0 & 1.4 & 826 & 2.2 & 2.2 \\
\hline Дубовский & 21,9 & 2 & $-1,7$ & 3 & $-9,59$ & 2 & 3,1 & 1 & 852 & 2 & 2,0 \\
\hline Заветинский & 16,7 & 1 & $-0,6$ & 3 & $-4,61$ & 3 & 2,2 & 1 & 776 & 3 & 2,2 \\
\hline Зимовниковский & 36,4 & 2 & $-1,4$ & 3 & $-6,98$ & 2 & 6,2 & 2 & 830 & 2 & 2,2 \\
\hline Орловский & 38,1 & 2 & $-2,7$ & 3 & $-8,64$ & 2 & 6,4 & 2 & 797 & 3 & 2,4 \\
\hline Ремонтненский & 18,1 & 1 & $-2,9$ & 3 & 0,50 & 4 & 3,1 & 1 & 903 & 1 & 2,0 \\
\hline
\end{tabular}

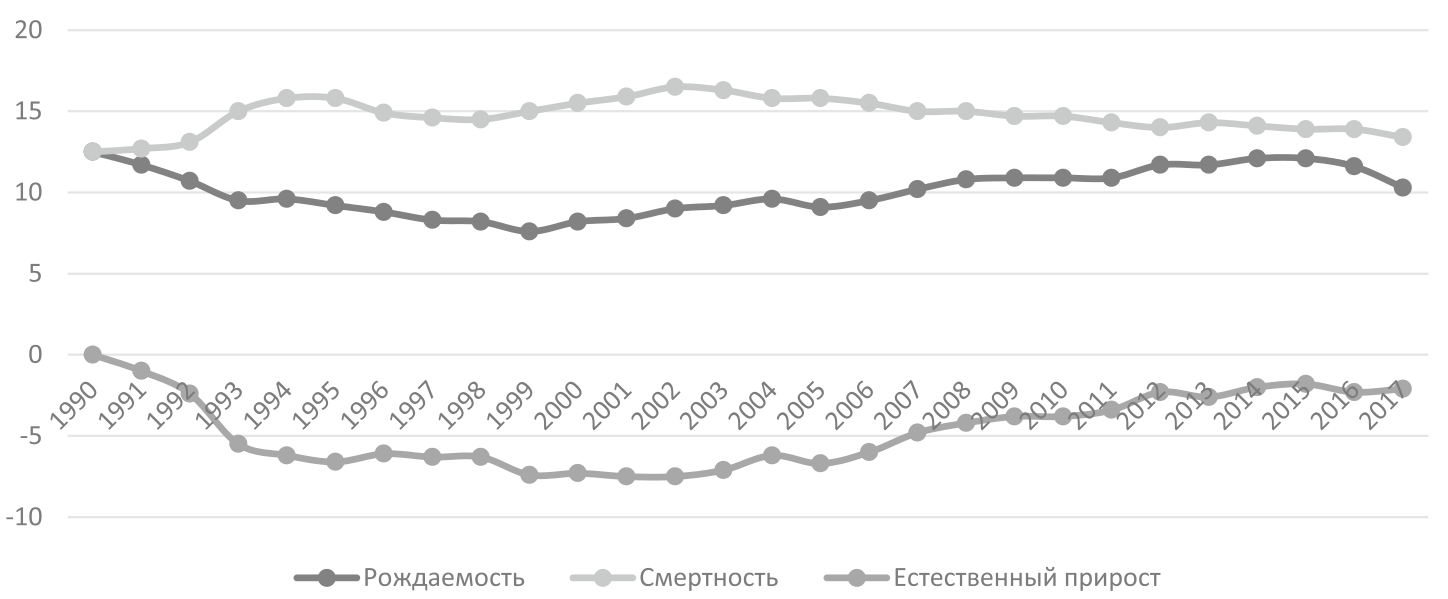

Рис. 1. Динамика показателей естественного движения населения Ростовской области, \%о, 1990-2017 г2. (составлено авторами по материалам [3; 4])

Повышенная смертность характерна для Гуково, Каменска-Шахтинского, Таганрога и 14 районов, расположенных преимущественно в Донецком, Северо-Западном и Южном комплексах. Самая негативная (до 18,1\%о) ситуация имеет место в Зверево, Белокалитвинском, Верхнедонском, Каменском, Милютинском, Песчанокопском, Тарасовском районах, расположенных соответственно в Донецком, Северо-Западном Северо-Восточном и Южном ТПАК.

В Юго-Западном и Южном ТПАК высокие показатели рождаемости совпадают с низкими значениями смертности населения. В то же время преобладание высокой смертности и низкой рождаемости характерно для одного из наиболее депрессивных - Донецкого ТПАК.

Eстественный прирост. Для Ростовской области в последние десятилетия характерная естественная убыль населения (рис. 1). Рассматривая пространственную дифференциацию естественного прироста (убыли) населения области, необходимо отметить, что в регионе нет ни одного муниципального образования, характеризующегося высоким естественным приростом. Прирост населения характерен для Батайска $(2,6 \%)$ за счет самого высокого показателя рождаемости в области и относительно низкого уровня смертности, а также для Аксайского $(0,8 \%$ ) и Мясниковского $(0,5 \%$ ) районов, являющихся частью интенсивно развивающейся Ростовской агломерации. Наибольшая естественная убыль характерна для Гуково, Кашарского, Тарасовского и Чертковского районов $(-9,-8,7 \%$ \%).

Наиболее благоприятная ситуация по совокупности демографических данных наблюдается в Юго-Восточном (-1,86\%), Юго-Западном $(-2,87 \%)$ и Центральном комплексах (-2,55\%о), а территории с самой 
высокой убылью расположены на северовостоке области (-6,02\%) и в Донецком ТПАК (-6,79\%о), что требует пристального внимания и выработки комплексных мер по развитию социально-экономической сферы их городов и районов.

Миграциионный прирост. Основным показателем, отражающим востребованность региона на рынке мобильных трудовых ресурсов, является миграционный прирост населения, который для области в 2017 г. составил 1907 человек, или 2,92\%о (17-е место в России). В динамике с 2012 по 2015 г. миграция в Ростовскую область многократно возросла за счет увеличения количества прибывших, после чего наблюдается возвращение прироста к показателям 2012 г. вследствие роста количества выбывших (рис. 2).

Ростовская область отстает от коэффициента миграционного прироста в целом по России в среднем на 1-1,5\%о, она следует в общей со всей страной динамике (табл. 4). Миграционные потоки в Ростовскую об- ласть в основном направлены из стран СНГ, наибольший вклад в миграцию вносят Украина и Армения, а также Узбекистан, Таджикистан и Казахстан [5].

Пространственная дифференциация миграционных потоков в Ростовской области ярко выражена. Наибольший коэффициент миграционного прироста наблюдается в Мясниковском (22,7\%о) и Аксайском $(11,4 \%$ районах, а также в Батайске $(13,9 \%$ ) и Ростове-на-Дону (4,4\%о). Наибольшая убыль (от (-10) до $(-14,7 \%$ )) отмечается в Гуково, Зверево, Песчанокопском, Кагальницком, Целинском и Багаевском районах.

Единственным территориальным природно-антропогенным комплексом c миграционным приростом является Юго-Западный, что объясняется наибольшей концентрацией городов и высоким уровнем экономического развития. Миграционная убыль наблюдается во всех остальных ТПАК, самыми убывающими являются Южный $(-8,04 \%$ и и Юго-Восточный $(-6,6 \%)$.

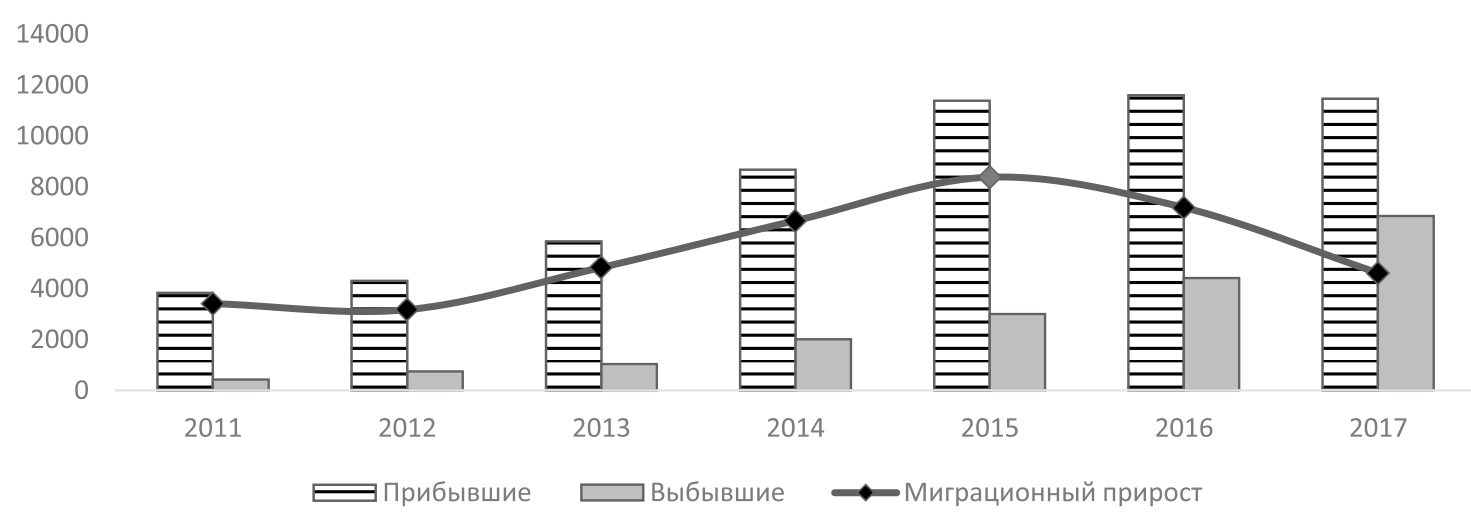

Рис. 2. Динамика миграционного прироста в Ростовской области из стран СНГ, тысс. чел., 2011-2017 22. (составлено авторами по материалам [3; 4])

Сравнительная динамика миграционного прироста в Ростовской области

Таблица 4 и Российской Федерации (составлено авторами по материалам [3; 4])

\begin{tabular}{|c|c|c|c|c|c|c|c|}
\hline Прирост, \% & 2011 & 2012 & 2013 & 2014 & 2015 & 2016 & 2017 \\
\hline \multicolumn{7}{|c|}{ Ростовская область } \\
\hline МП из СНГ & 0,9 & 1,01 & 1,38 & 2,04 & 2,68 & 2,74 & 2,71 \\
\hline МП Общий & 1,05 & 1,2 & 1,61 & 2,23 & 2,9 & 2,92 & 2,92 \\
\hline \multicolumn{8}{|c|}{ Российская Федерация } \\
\hline МП из СНГ & 2,17 & 2,55 & 2,95 & 3,68 & 3,66 & 3,48 & 3,57 \\
\hline МП Общий & 2,49 & 2,92 & 3,36 & 4,11 & 4,09 & 3,91 & 4,01 \\
\hline
\end{tabular}


В совокупности показателей естественного и механического прироста наблюдается сокращение числа жителей, затронувшее с 2003 по 2017 год большинство городов и районов области. Исключением являются только Ростов-на-Дону, Батайск, Аксайский и Мясниковский районы, которые входят в зону Ростовской агломерации, занимающей 5,3\% территории и концентрирующей около $40 \%$ населения региона, а также Юго-Западный ТПАК, являющийся наиболее развитой частью области.

Наиболее выраженная депопуляция населения за рассмотренные 14 лет наблюдалась в Зверево $(30,8 \%)$, Милютинском $(25,4 \%)$, Верхнедонском $(22,7 \%)$, Зерноградском (19,5\%) и Тацинском (19\%) районах. Существенная убыль населения (от 10 до 18\%) также зафиксирована в Боковском, Кагальницком, Каменском, Кашарском, Константиновском, Мартыновском, Морозовском, Октябрьском, Песчанокопском, Ремонтненском, Советском, Тарасовском, Целинском, Чертковском и Шолоховском районах.

Трудоспособное население. В Юго-Западном ТПАК наблюдается самая высокая доля трудоспособного населения по Ростовской области, составляющая $57,4 \%$. Наибольшее число трудоспособных отмечается в Новочеркасске (59,8\%), Ростове-на-Дону (59\%) и Аксайском районе $(58,4 \%)$. В это же время в Неклиновском, Куйбышевском и Матвеево-Курганском сельских районах данные показатели не превышают 53,5 \% из-за оттока трудоспособного населения в близко расположенные крупные города в поисках лучших условий жизни.

Вторым ТПАК с высокими показателями трудоспособного населения является Северо-Западный со средним значением, равным $57 \%$, в котором в положительную сторону (54-54\%) выделяются Кашарский и Миллеровский районы, а самая низкая доля (52\%) отмечена в Верхнедонском районе.

Повышенные показатели доли трудоспособного населения характерны для Донецкого $(53,9 \%)$, Центрального $(53,7 \%)$ и Юго-Восточного $(54,7 \%)$ комплексов. В представленных ТПАК высокая доля трудящихся (55-59\%) свойственна Октябрьскому, Веселовскому и Заветинскому районам, а низкая (51-53\%) - Белокалитвинскому, Семикаракорскому и Ремонтненскому. Наименьшая доля трудоспособного населения прослеживается в Южном $(53,2 \%)$ и Севе-
ро-Восточном ТПАК $(38,6 \%)$, что на $16,8 \%$ меньше, чем средние показатели по области.

Демографическая нагрузка. Коэффициент общей демографической нагрузки является важнейшим индикатором, отображающим общую социально-экономическую ситуацию в Ростовской области. На его дифференциацию внутри области оказывают влияние различные факторы, среди которых важнейшими являются дисбаланс в социально-экономическом развитии, различная степень транспортной доступности, природные условия и факторы. Повышенная демографическая нагрузка наблюдается в Юго-Западном ТПАК (741 чел. на 1000 населения), и в частности в Ростове-на-Дону (694). Нагрузка на трудоспособное население здесь самая низкая, поскольку рассматриваемая территория является ядром центрального ареала расселения, генерируя основную часть экономического потенциала области и привлекая в большом количестве рабочую силу. В остальных ТПАК Ростовской области наблюдается высокая демографическая нагрузка, наибольших значений (932-973) она достигает в Белокалитвинском, Каменском, Семикаракорском, Песчанокопском, Милютинском и Цимлянском районах.

Демографический потенцииал. По итогам анализа отдельных показателей (численность населения, естественный прирост, миграционный прирост, численность работающих, демографическая нагрузка) проведена оценка демографического потенциала территории Ростовской области по состоянию на 2017 год. Полученные результаты представлены в разрезе ТПАК и отдельных муниципальных образований (табл. 3, рис. 3).

Полученное пространственное распределение демографического потенциала демонстрирует наиболее перспективные и депрессивные территории региона. В целом можно сказать, что полученные результаты соответствует центрально-периферийной модели развития. Центру соответствует Ростовская агломерация, ядром которой является г. Ростов-на-Дону и прилегающие города, и районы с развитой социальной сферой и диверсифицированной структурой экономики. Закономерно, что при таких условиях данная территория привлекает население и обладает самым высоким демографическим потенциалом в регионе.

Практически все остальные территории области обладают пониженным демографическим потенциалом. В свою очередь 
самый низкий демографический потенциал наблюдается в наименее развитых районах севера области: Боковском, Верхнедонском, Кашарском, Милютинском и Обливском. Данная ситуация обусловлена периферийностью их положения: слабой транспортной доступностью, не диверсифицированной экономикой, отсутствием перспективных рабочих мест, низким доходом жителей и неразвитой социальной инфраструктурой.

Ряд районов крайнего юго-востока имеют относительно высокий демографический потенциал, что может объясняться специфической структурой местного сельскохозяйственного производства, основу которого составляет овцеводство, что привлекает в эти места сельских жителей Кавказа, традиционно занятых в данной отрасли и отличающихся повышенными коэффициентами рождаемости.

Относительно высокий демографический потенциал Миллеровского и Сальского районов связан с тем, что городские поселения Миллерово и Сальск представляют собой агропромышленные центры с развивающейся относительно диверсифицированной экономикой и транспортной инфраструктурой.

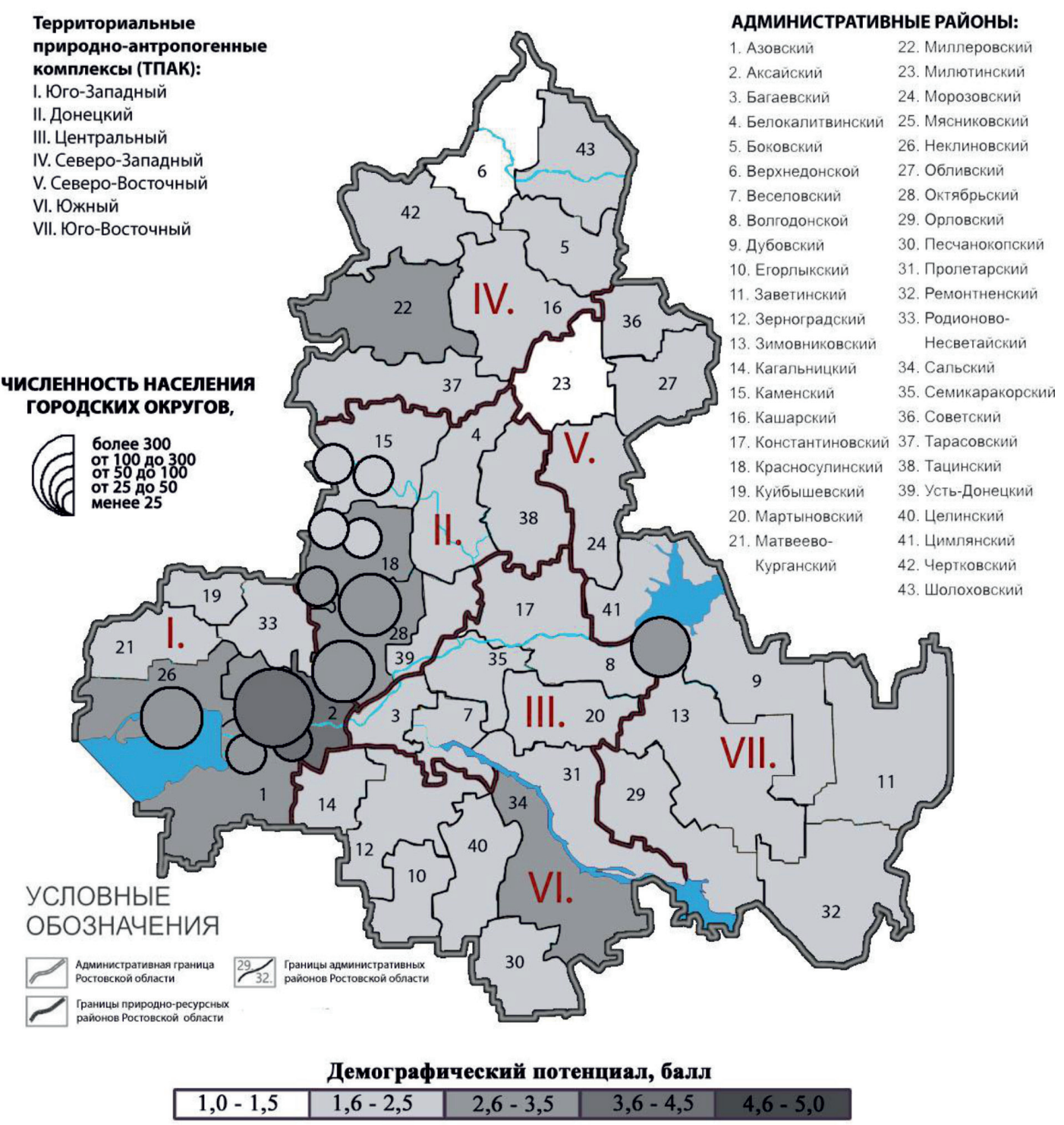

Рис. 3. Демографический потенциал городских округов и административньх районов Ростовской области, 2017 г. (составлено авторами) 


\section{Выводы}

1. Ростовская область является регионом, на протяжении последних десятилетий испытывающим процессы депопуляции, которые не компенсируется стабильным, но незначительным миграционным приростом. Большинство депрессивных территорий расположены в северной, северо-восточной и юго-восточной частях Ростовской области. Стабильная демографическая ситуация наблюдается в юго-западной части региона.

2. В условиях старения населения, депопуляции и дефицита рабочей силы в области отмечается существенная территориальная дифференциация демографической нагрузки. Относительно благоприятная ситуация сложилась в Юго-Западном ТПАК, экономическом лидере области, создающем новые рабочие места и предлагающем карьерные перспективы для молодежи. В остальных территориях области, напротив, развивающаяся безработица, отток квалифицированных кадров при одновременном росте пожилого населения приводят к возрастанию нагрузки на трудоспособное население.

3. Демографический потенциал Ростовской области характеризуется значительной территориальной дифференциацией по принципу «центр - периферия». Центром выступает г. Ростов-на-Дону и прилегающие к нему муниципальные районы, полупериферия включает в себя города и районы на удалении в 200-250 километров от центра, а к периферии относятся наиболее удаленные районы крайнего севера и восто- ка области, качественно выделяющиеся по всем рассматриваемым индикаторам.

Исследование выполнено при финансовой поддержке РФФИ в рамках научного проекта № 20-35-90094.

\section{Список литературы / References}

1. Райзберг Б.А., Лозовский Л.Ш., Стародубцева Е.Б. Современный экономический словарь. 6-е изд., перераб. и доп. М.: ИНФРА-М, 2011. 512 с.

Raizberg B.A., Lozovsky L.Sh., Starodubtseva E.B. Modern economic dictionary. 6th ed., Rev. and additional. M.: INFRA-M. 2011. 512 p. (in Russian).

2. Иванченко А.М., Коновалов А.Н., Бессмертный И.В., Хованский А.Д., Латун В.В., Меринова Ю.Ю. Природный потенциал ландшафтов Ростовской области // Известия высших учебных заведений. Северо-Кавказский регион. Естественные науки. 2019. № 4. С. 62-70.

Ivanchenko A.M., Konovalov A.N., Bessmertnyi I.V., Khovanskiy A.D., Latun V.V., Merinova Yu.Yu. Natural potential of the landscapes of the Rostov region // Izvestiya vysshih uchebnyh zavedenij. Severo-Kavkazskij region. Estestvennye nauki. 2019. N. 4. P. 62-70 (in Russian).

3. Статистический сборник «Сравнительные показатели социально-экономического положения городских округов и муниципальных районов Ростовской области. 2014»: Стат. сб./Ростовстат. Ростов н/Д., 2015. 395 с.

Statistical Bulletin «Comparative indicators of socioeconomic status of urban districts and municipal districts of the Rostov region. 2014»: Stat. sb./Rostovstat. Rostov n/D., 2015. 395 p. (in Russian).

4. Статистический сборник «Сравнительные показатели социально-экономического положения городских округов и муниципальных районов Ростовской области. 2017»: Стат. сб./Ростовстат. Ростов н/Д., 2018. 395 с.

Statistical Bulletin «Comparative indicators of socioeconomic status of urban districts and municipal districts of the Rostov region. 2017»: Stat. sb./Rostovstat. Rostov n/D., 2018. 395 p. (in Russian).

5. Денисова Г.С., Шурыгина Е.Г. Миграционная ситуация в регионах Юга России в 2019 г. в оценках экспертов // Гуманитарий Юга России. 2019. № 6. С. 277-289.

Denisova G.S., Shurygina E.G. The migration situation in the regions of the South of Russia in 2019 in the estimates of experts // Gumanitariy Yuga Rossii. 2019. No. 6. P. 277289 (in Russian). 